\title{
Prototype Design Of Micro Hydro Using Turbine Archimedes Screw For Simulation Of Hidropower Practical Of Electro Engineering Students
}

\author{
Antonius Ibi Weking ${ }^{*}$, Yanu Prapto Sudarmojo ${ }^{2}$ \\ 1,2 Departement of Electrical Engeneering \\ Faculty of Engeneering \\ Udayana University \\ Bali- Indonesia 80361 \\ *tony@unud.ac.id
}

\begin{abstract}
Micro Hydro is a micro hydropower plant (MHP) on a small scale. The main problem from micro hydropower plants is a water discharge which it's flow is not continued every year because influenced by weather season. To knowing a right of micro hydro 's characteristic is not an easy thing to learn it, because a characteristic each of micro hydro's installation location is considered a specific location. One type of micro hydro is using Archimedes Screw Turbine. Udayana University of Electrical Engineering Department in this time does not have a facility for the hydropower field to use this model, so a college student less to receive a knowledge of this. Through this research, a writer wants to expand a college student's knowledge in the hydropower field with creating a prototype of micro hydro with Archimedes Screw Turbine to hydropower practical in a laboratory. In this study will discuss the influence of water pressure and slope of the altitude angle on the rotation produced by the Archimedes screw turbine so that it can be seen the voltage, current, power generated by the generator, torque and efficiency. The result of from handmade equipment for this research in angle $40^{\circ}$ with biggest generator round (rpm) is $3765(\mathrm{rpm})$ and highest power is 10.91096 watt, torque is $0.60257 \mathrm{Nm}$ dan efficiency is about $14.07 \%$. The torque which resulted from water pressure $24 \mathrm{psi}$ is $0.703 \mathrm{Nm}$ and efficiency $17.594 \%$. The voltage, current, and output power which resulted in the generator is 83.8 Volt, 0.1932 Ampere and 1619 Watt. For generator speed round in the pressure, 24 Psi is $4579 \mathrm{rpm}$, while turbine speed round which resulted from the pressure 24 Psi is $380 \mathrm{rpm}$ before coupled with the generator and $220 \mathrm{rpm}$ after coupled with a generator.
\end{abstract}

\section{Index Term : Prototype MHP, Archimedes Screw Turbine, Screw Angle, Pressure, efficiency}

\section{INTRODUCTION}

Micro hydro or so be called Microhydro Power Plants is a small scale power plant which use water power as a power drive such as irrigation drain, river, or nature waterfall with a made use of its water level (head) and a total of water debit. One of the most important components in a micro hydropower plant is a turbine. Turbine has a function to convert energy potential and kinetic energy from water to mechanic energy. There is a lot of turbine type which used in micro hydropower plants, one of those is Screw Turbine. Screw Turbine is one of the turbines which is working to an area that had the lowest head such as irrigation drain.

The research which will discuss is Micro hydropower plants with using Screw Turbine. This turbine is operated with low round and it's still new in Indonesia. Especially in Bali already developing Micro Hydro Power Plants with Screw Turbine which developed in Jatiluwih tourism region, 
Tabanan District. The research very difficult to do in real conditions to do because some factor that slowing the research such as nature factor, environmental factor, economic factor, and culture customs factor. From that, the researcher interested to create a prototype of Micro Hydro Power Plants with laboratory scale Screw Turbine and practical purpose. With this prototype can learned directly characteristics micro hydro which is very useful for college student. This study will specifically study the effects of water pressure, slope angle to get maximum output power from a microhydro prototype.

\section{METHOD}

\section{WATER POWER PLANTS}

\section{A. Micro Hydro Power Plants}

Micro hydro or so be called Micro Hydro Power Plants, is a small scale power plant which use water power as power drives such as irrigation drain, river, or nature waterfall with a made use of its high touch (head) and a total of water debit. Technically, micro-hydro has three main components that are water (as an energy source), turbine and generator. Micro-hydro get the energy from water flow which has a certain height difference. Basically, microhydro make use of waterfall potential. Higher of the waterfall, then bigger water potential energy that can be changed to electric energy.

A principal of Microhydro Power Plants is using a water debit total which flowing in river flow, waterfall, or drain and use the difference of water flow heights. A water flow that impacts to turbine causing turbine will round so would produce mechanic energy. Mechanic energy which produced then will move a generator and producing electric energy. [1][2][3]

\section{B. Screw Turbine Slope}

The sharp position of the tilt of the turbine Screw to determine the high speed and water pressure in moving the turbine, the greater the pressure or speed of the water, the turbine power rotation will be faster which gives the output power effect generated from the generator, as in Figure 1.
However, the slope excessive will cause reduction [2]

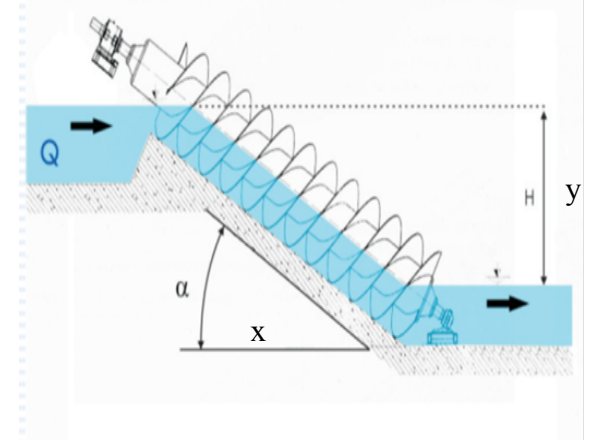

Figure 1: Screw Turbine Slope

Slope degree can be determined with a equation :

$\tan \alpha=\mathrm{y} / \mathrm{x} \quad \alpha=\tan ^{-1}(\mathrm{y} / \mathrm{x})$

Where :

$\begin{array}{ll}\text { Tan } \alpha & =\text { slope degree } \\ \mathrm{y} & =\text { vertical range } \\ \mathrm{x} & =\text { horizontal range }\end{array}$

Power which produced in Micro Hydro Power Plants modelling with screw turbine can be calculated with a equation :[3]

Pout $=$ V .I

Where :

Pout = Output Power (watt)

$\mathrm{V}=$ Voltage $($ Volt $)$

I $\quad=$ Current $(\mathrm{A})$

C. Archimedes Screw Turbine

Archimedes Screw Turbine (Archimedes Screw) is one of a special turbine because can be operated to a very low area. Archimedes screw consisting helix surface which around cylinder axis center such as Figure 2. [4] When used as a pipe, the screw usually rotated by the generator or manual power force. When the axis is rotated, the lower end rolls up water volume that called bucket. These water will launch to the spiral tube until finally burst out from the upper screw. Screw pump used especially to flowing water out from mine or another area from the lowest water. Opened trough and overall design make possible of debris track without clogging 


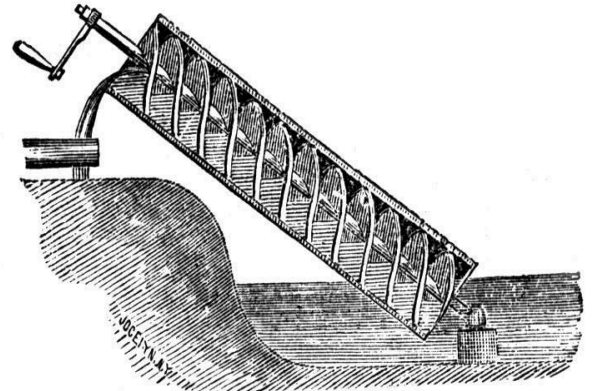

Fig. 2: Archimedes Screw Turbine

Beside known as screw turbine, corresponding with a first concept, these turbine is also called Archimedes Screw. Screw turbine is a better use of low head or different elevation between low flow even zero upstream and downstream. Archimedes screw turbine can be used in low water hydro site as a tool producing electric. This can be done with operating Archimedes Screw reversely, is dropping water from above and let screw rotates when water is drop down. This is an economical way and efficient to generate an electric from a small flow. The screw is rotated and generate electric because of hydrostatic pressure from water in screw surface. When water is filling screw from entrance line in a top of the slope, a pressure at helix field's screw makes possible to screw rotation. These Archimedes screw's work principal is, water from top end flowing into the space between blade screw range and flow out from the bottom end, so will inflict water gravity and hydrostatic pressure difference in the bucket around rotor that pushing blade screw and rotate a rotor in its axis. Then the turbine rotor will be rotates electric generator which is connected with a screw turbine's top end axis.

D. Archimedes Screw Turbine Advantage

There is an advantage of Archimedes Screw Turbine compared of another turbine is :

1) Good developed to an area which has bigger water source debit but has a small head.

2) Not need a complicated control system just like other turbines.

3) Water pressure of the turbine is not damaging ecology, in other words, impact to water species (fish).
4) It does not need draft tube so can reduce the cost to draft tube installation dig.

5) Has a high efficiency, with a big debit variation and very good to small debit water.

6) It does not need to use fine nets as a barrier of debris to a turbine, so can reduce maintenance cost..

E. Hydrolic Power and Efficiency

Water debit is a magnitude that declares how many waters flowed at one time which passing a wide cross-section. Testing of water debit is purposed to know how much water that flow in volume unit per time unit. to calculate water debit value, can use the equation below : [5]

$$
\text { Debit }=\frac{\text { Vessel Volume }}{\text { VesselFulfilled Time }}
$$

Hydraulic power is a power generated from flowing water from some heights. From this, hydraulic power can get from water power which generated from a pump: [5][6][7][8]

$$
\mathrm{P}=\rho . \mathrm{Q} \cdot \mathrm{h} . \mathrm{g}
$$

Explanation:

$\mathrm{P}=$ Hydrolic Power (Watt)

$\rho=$ Fluida/water density $\left(\mathrm{kg} / \mathrm{m}^{3}\right)$

$\mathrm{Q}=$ Water Debit $\left(\mathrm{m}^{3} / \mathrm{s}\right)$

$\mathrm{g}=$ Gravity $\left(\mathrm{m} / \mathrm{s}^{2}\right)$

$\mathrm{H}=$ Head or High water drop (m)

Efficiency System ( $\Pi$ Micro Hydro Power Plants) is a plant tool ability to change kinetic energy from flowed water to electric energy. To calculate efficiency can use an equation 5: [9][10]

$$
\eta_{\text {PLTMH }}=\frac{\mathrm{P}_{\mathrm{G}}}{\mathrm{P}_{\mathrm{H}}} \times 100 \% \text { atau } \frac{\mathrm{P}_{\mathrm{OUT}}}{\mathrm{P}_{\mathrm{IN}}} \times 100 \%
$$

Explanation:

$$
\begin{aligned}
& \eta_{P L T M H}=\text { Micro Hydro Power Plants Efficiency } \\
& \text { System } \\
& P_{G}=\text { Generator Power } \\
& P_{H}=\text { Hydrolic Power }
\end{aligned}
$$




\section{F. Torque}

Torque is a magnitude which declares how much force that is working at the object so causing the rotating object. To calculate torque, can use an equation below:

$$
\mathrm{T}=\frac{\mathrm{P}}{2 \pi \frac{\mathrm{N}}{60}}
$$

Explanation:

$$
\begin{aligned}
& \mathrm{T}=\text { Torque }(\mathrm{Nm}) \\
& \mathrm{P}=\text { Power }(\mathrm{kW}) \\
& \mathrm{N}=\text { Rounding Speed }(\mathrm{rpm})
\end{aligned}
$$

\section{RESULT AND DISCUSION}

A. Micro Hydro Power Plants System Model Design.

Designing Micro Hydro Power Plants System and designing turbine design which would use in this research, and design turbine which would use in this research. This is a planning table which can be seen in Table 1 and Table 2 about modeling system of Micro Hydro Power Plants in this research:

TABLE1.

MICRO HYDRO POWER PLANTS PLANNING SYSTEM

\begin{tabular}{|l|c|}
\hline \multicolumn{1}{|c|}{ Parameter } & Value \\
\hline Volume Box & 220 liter \\
\hline Head Netto & $134 \mathrm{~cm}$ \\
\hline $\begin{array}{l}\text { Turbine building } \\
\text { length }\end{array}$ & $150 \mathrm{~cm}$ \\
\hline $\begin{array}{l}\text { Turbine building } \\
\text { Diameter }\end{array}$ & $28 \mathrm{~cm}$ \\
\hline Diameter pipe & $7.6 \mathrm{~cm}$ \\
\hline Fast Pipe Length & $300 \mathrm{~cm}$ \\
\hline
\end{tabular}

TABLE 2

TURBINE SPECIFICATION

\begin{tabular}{|l|c|}
\hline Parameter & Value \\
\hline Turbine Diameter & $26 \mathrm{~cm}$ \\
\hline Turbine Spoke & $13 \mathrm{~cm}$ \\
\hline Blade screw thick & $0.25 \mathrm{~cm}$ \\
\hline Blade screw range & $17 \mathrm{~cm}$ \\
\hline Blade Screw height & $10 \mathrm{~cm}$ \\
\hline Blade screw amount & $1 \mathrm{buah}$ \\
\hline $\begin{array}{l}\text { Twisted screw } \\
\text { amount }\end{array}$ & $10 \mathrm{buah}$ \\
\hline Blade screw angle & $24^{0}$ \\
\hline Main Axis Diameter & $2.5 \mathrm{~cm}$ \\
\hline Outer Axis Diameter & $6 \mathrm{~cm}$ \\
\hline Main axis length & $215 \mathrm{~cm}$ \\
\hline Outer axis length & $150 \mathrm{~cm}$ \\
\hline Turbine Heavy & $24 \mathrm{~kg}$ \\
\hline
\end{tabular}

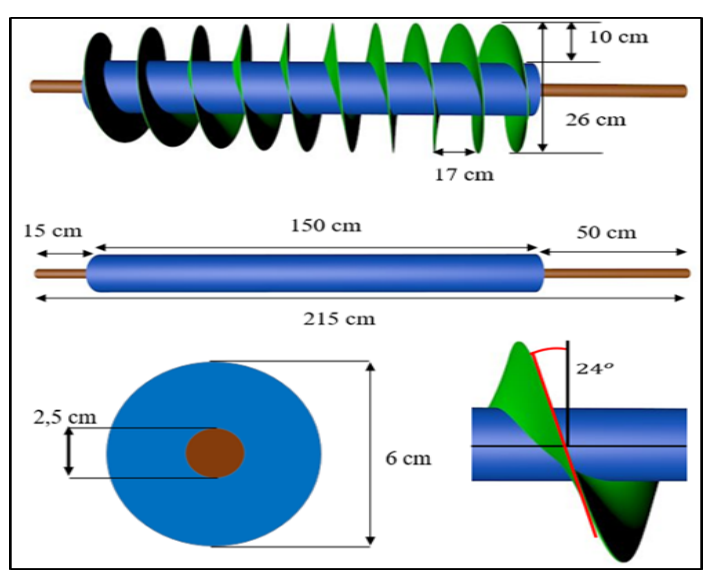

Fig. 3. Planning Design

\section{B. Prototype Creation}

In a later testing, prototype is formed within 2 type, it is to measurement of effect tubine head slope and effect of water pressure. 


\section{Slope Modelling dan how it works}

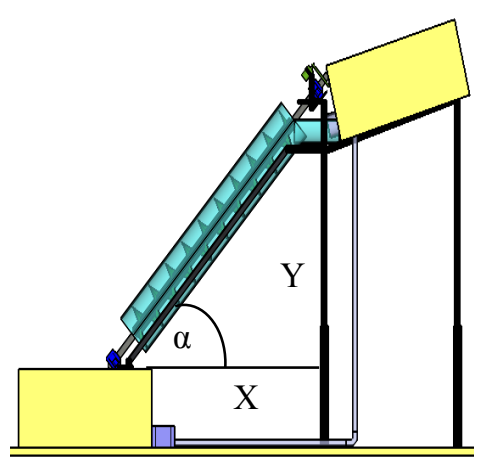

Fig 4. Turbine Head Modelling Position

The way work for this modeling is a pump will be drawn water in the bucket, and then water will be flowing through a pipe to water shelter, which it's installed in turbine head, collect it back to a bucket. The water will be flowing to the turbine strip and the turbine is rotating so will cause turbine mechanic energy to be rotates; a turbine is connected with a pulley turbine through an axis. With a belt, turbine pulley is connected with a pulley, which is already connected to generator rotor (pulley generator). The generator will change mechanic energy from the turbine into electric energy. To measure turbine spin and generator, it uses with a tachometer while voltmeter and amperemeter are used to measure voltage and current which generated through a generator.

\section{Pressure Modelling}

The way it works for this modeling is first, the water in the tub is pumped up (see fig. 5), then the water will flow to the Archimedes screw turbine blades. Water from the top end of the pipe flows into the space between the screw in the ranged blade and the lower end comes out. This will cause a difference in water gravity and hydrostatic pressure around the axis of the turbine and the turbine axis rotating on its axis. Then the pulley at the top end of the turbine axis rounds up the electric generator, which connects to the pulley in the generator. In a generator, he has installed a voltmeter and an ammeter to measure the voltage and current, which is produced from a generator. Manometer devices are installed in pipes to measure water pressure while tachometers are used to measure turbines and turbine generators.
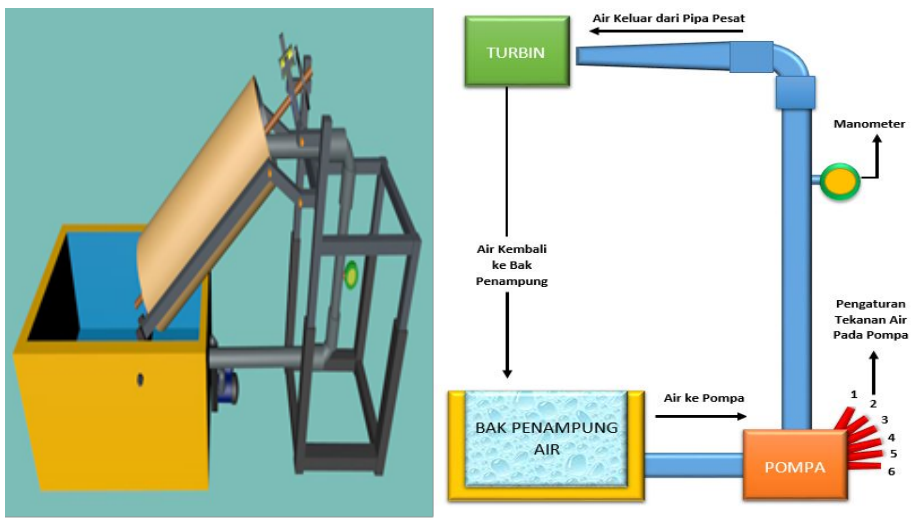

Fig. 5. Water Pressure Measurement Modelling C. Realization Of Screw Mhp Prototype
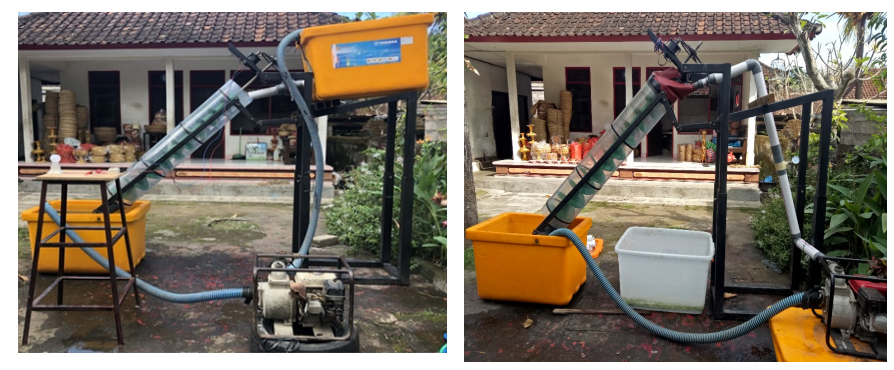

a) Model of Slope Degree b) Model of Water Pressure

Fig. 6. Realization Of Screw Mhp Prototype

D. Measurement and Calculation Effect Of Slope Degree

Data analysis in this research using quantitative data. A quantitative data in this research is got from every testing result where the testing is done by 5 times measurements every parameter to get an accurate result with screw turbine head slope angle variation and water pressure. From five testing, its data result is an average of the testing. In this testing, angle $\alpha$ thus creating a variation with change heights corresponding with water drop at pinwheel from turbine head angle position at $0^{0}, 10^{\circ}, 15^{0}, 20^{\circ}$, $25^{\circ}, 30^{\circ}, 35^{\circ}, 40^{\circ}, 45^{\circ}, 50^{\circ}, 55^{\circ}, 60^{\circ}, 70^{\circ}, 80^{\circ}$ and $90^{\circ}$ 
1. Calculation Of Slope Degree

In this measurement needs to be determined a stable water debit in order the result of measurement is not changed. The capacity of water used is 210 liters and the time needed for filling is 36 seconds.

$$
\mathrm{Q}=\frac{210}{36}=5.831 \mathrm{t} / \mathrm{s}
$$

Slope degree measurement is determined with knowing vertical range $(\mathrm{y})$ and horizontal range $(\mathrm{x})$ and determined with an equation which calculated from $10^{0}$ :

$$
\begin{aligned}
& \tan \alpha=y / x \quad \alpha=\tan ^{-1}(\mathrm{y} / \mathrm{x}) \\
& \tan \alpha=36 / 210 \quad \alpha=\tan ^{-1}(36 / 210)=10^{0}
\end{aligned}
$$

TABLE 3

CALCULATION OF SLOPE DEGREE

\begin{tabular}{|c|c|c|}
\hline $\begin{array}{c}\text { Vertical Range } \\
(\mathrm{y}) \\
(\mathrm{cm})\end{array}$ & $\begin{array}{c}\text { Horizontal } \\
\text { Range (x) } \\
(\mathrm{cm})\end{array}$ & $\begin{array}{c}\text { Slope Degree } \\
\alpha^{0}\end{array}$ \\
\hline 0 & 215 & 0 \\
\hline 36 & 210 & 10 \\
\hline 55 & 205 & 15 \\
\hline 72 & 200 & 20 \\
\hline 89 & 195 & 25 \\
\hline 104 & 190 & 30 \\
\hline 120 & 185 & 35 \\
\hline 134 & 180 & 40 \\
\hline 147.5 & 175 & 45 \\
\hline 160 & 170 & 50 \\
\hline 173 & 155 & 55 \\
\hline 186 & 145 & 60 \\
\hline 196.5 & 100 & 70 \\
\hline 205 & 65 & 80 \\
\hline 215 & 0 & 90 \\
\hline
\end{tabular}

2. Calculation Of Hydrolic Power

To know about hydrolisis power or power which resulted from water from some heights calculated from angle $10^{\circ}$, because from an angle $0^{0}$ it's have no heights, a calculation can be done with this equation :

$\mathrm{P}=$ p.Q.h.g $=1000 * 0.0059 * 0.36 * 9.81=21.89$ watt
TABLE 4

CALCULATION OF HYDROLIC POWER

\begin{tabular}{|c|c|c|}
\hline Angle $\alpha^{0}$ & Heights (head) & Hydrolic Power / Pin \\
\hline 0 & 0 & 0 \\
\hline 10 & 36 & 21,89 \\
\hline 15 & 55 & 31.83 \\
\hline 20 & 72 & 41.67 \\
\hline 25 & 89 & 51.51 \\
\hline 30 & 104 & 60.19 \\
\hline 35 & 120 & 69.45 \\
\hline 40 & 134 & 77.55 \\
\hline 45 & 147.5 & 85.37 \\
\hline 50 & 160 & 92.6 \\
\hline 55 & 173 & 100.13 \\
\hline 60 & 186 & 107.65 \\
\hline 70 & 196.5 & 113.73 \\
\hline 80 & 205 & 118.65 \\
\hline 90 & 215 & 124.43 \\
\hline
\end{tabular}

3. Pout Calculation

Using equation 2 can be calculated Pout

TABLE 5

MEASUREMENT AND CALCULATION THE

\begin{tabular}{|c|c|c|c|c|c|c|c|c|c|c|}
\hline \multirow[b]{2}{*}{ No } & \multirow{2}{*}{$\begin{array}{c}\text { Turbine } \\
\text { Angle } \\
\alpha^{0} \\
\end{array}$} & \multicolumn{2}{|c|}{$\begin{array}{l}\text { Turbine Round } \\
\text { (rpm) }\end{array}$} & \multirow{2}{*}{$\begin{array}{c}\text { Gener } \\
\text { ator } \\
\text { Round } \\
(\text { rpm) }\end{array}$} & \multicolumn{3}{|c|}{ Without Loss } & \multicolumn{3}{|c|}{60 watt lamp } \\
\hline & & \begin{tabular}{|c|} 
Before \\
Coupled
\end{tabular} & \begin{tabular}{|c|}
$\begin{array}{c}\text { After } \\
\text { Coupled }\end{array}$ \\
\end{tabular} & & $\begin{array}{c}\mathrm{V} \\
\text { (volt) }\end{array}$ & $\begin{array}{c}\mathrm{I} \\
(\mathrm{mA}) \\
\end{array}$ & $\begin{array}{c}\mathbf{P} \\
\text { (watt) }\end{array}$ & $\begin{array}{c}\mathbf{V} \\
\text { (volt) }\end{array}$ & \begin{tabular}{|c|}
$\mathbf{I}$ \\
$(\mathbf{m A})$
\end{tabular} & P (watt) \\
\hline 1 & 0 & \begin{tabular}{|l|}
- \\
\end{tabular} & - & - & - & \begin{tabular}{|l|}
- \\
\end{tabular} & \begin{tabular}{|l|}
- \\
\end{tabular} & & - & - \\
\hline 2 & 10 & 183 & 14 & 344 & 18.2 & - & - & - & - & - \\
\hline 3 & 15 & 211 & 44 & 525 & 25.1 & - & - & 12.5 & 72.41 & 0.905125 \\
\hline 4 & 20 & 260 & 73 & 2141 & 42.1 & - & - & 24.32 & 104.51 & 2.541683 \\
\hline 5 & 25 & 282 & 132 & 2573 & 66.38 & - & - & 42.38 & 120.44 & 5.104247 \\
\hline 6 & 30 & 290 & 141 & 2816 & 70.32 & - & - & 51.47 & 129.36 & 6.658159 \\
\hline 7 & 35 & 293 & 159 & 3516 & 84.33 & - & - & 58.54 & 137.44 & 8.045738 \\
\hline 8 & 40 & 301 & 173 & 3765 & 101.53 & - & - & 73.43 & 148.59 & 10.91096 \\
\hline 9 & 45 & 294 & 160 & 3562 & 98.65 & - & - & 69.42 & 146.44 & 10.16586 \\
\hline 10 & 50 & 273 & 133 & 2626 & 60.69 & - & - & 48.53 & 118.14 & 5.733334 \\
\hline 11 & 55 & 269 & 108 & 2591 & 55.71 & - & - & 28.33 & 94.44 & 2.675485 \\
\hline 12 & 60 & 256 & 92 & 1862 & 45.29 & - & - & 22.6 & 90.53 & 2.045978 \\
\hline 13 & 70 & 252 & 72 & 1841 & 38.36 & - & - & 20.32 & 81.41 & 1.654251 \\
\hline 14 & 80 & 180 & - & - & - & - & - & - & - & - \\
\hline 15 & 90 & 168 & - & - & - & - & - & - & - & - \\
\hline
\end{tabular}
EFFECT OF ANGULAR HEIGHT

4. Calculation of efficiency and Torque 
Using equation 5 and 6 can be calculated through Efficiency and Torque. To measure maximum efficiency at angle $40^{\circ}$ :

$$
\eta=\frac{P_{\text {out }}}{P_{\text {in }}} \times 100 \%=\frac{10.91096}{77.55} \times 100 \%=14.07 \%
$$

To measure maximum Torque at angle $40^{\circ}$

$$
T=\frac{P}{2 \pi \frac{n}{60}}=\frac{10.91096}{2 * 3.14 * \frac{173}{60}}=0.60257 \mathrm{Nm}
$$

TABLE 6

EFFICIENCY CALCULATION

\begin{tabular}{|c|c|c|c|}
\hline Turbine Angle & Input Power & Output Power & Efficiency (\%) \\
\hline 0 & & 0 & 0 \\
\hline
\end{tabular}

\begin{tabular}{|c|c|c|c|}
\hline 0 & 0 & 0 & 0 \\
\hline 10 & 21.89 & 0 & 0 \\
\hline 15 & 31.83 & 0.905125 & 2.843622 \\
\hline 20 & 41.67 & 2.541683 & 6.099551 \\
\hline 25 & 51.51 & 5.104247 & 9.909235 \\
\hline 30 & 60.19 & 6.658159 & 11.061902 \\
\hline 35 & 69.45 & 8.045738 & 11.584936 \\
\hline 40 & 77.55 & 10.91096 & 14.069581 \\
\hline 45 & 85.37 & 10.16586 & 11.908000 \\
\hline 50 & 92.6 & 5.733334 & 6.191505 \\
\hline 55 & 100.13 & 2.675485 & 2.672011 \\
\hline 60 & 107.65 & 2.045978 & 1.900583 \\
\hline 70 & 113.73 & 1.654251 & 1.454542 \\
\hline 80 & 118.65 & 0 & 0 \\
\hline 90 & 124.43 & 0 & 0 \\
\hline
\end{tabular}

E. Measurement and Calculation Effect Of Water Pressure

To water pressure is the same. it's data taken from an average of 5 testing. It's testing data taken from 4 psi, 8 psi, 12 psi, 16 psi, 20 psi, and 24 psi.

\section{Pout Calculation}

Using equation 2 can be calculated Pout
TABLE 7

MEASUREMENT AND CALCULATION EFFECT

\begin{tabular}{|c|c|c|c|c|c|c|c|c|c|c|}
\hline \multirow[b]{2}{*}{ No } & \multirow{2}{*}{$\begin{array}{c}\text { Water } \\
\text { Pressure } \\
\text { (psi) }\end{array}$} & \multicolumn{2}{|c|}{ Turbine Round (rpm) } & \multirow{2}{*}{$\begin{array}{c}\text { Generator } \\
\text { Round } \\
(\mathrm{rpm})\end{array}$} & \multicolumn{3}{|c|}{ Without Loss } & \multicolumn{3}{|c|}{ Loss } \\
\hline & & $\begin{array}{c}\text { Before } \\
\text { Coupled } \\
\end{array}$ & $\begin{array}{c}\text { After } \\
\text { Coupled } \\
\end{array}$ & & V & I & $\mathrm{P}$ & V & I & $P$ \\
\hline 1 & 4 & 176 & - & - & - & - & - & - & - & - \\
\hline 2 & 8 & 222 & 48 & 942 & 29.1 & - & - & 14.9 & 0.0873 & 1.3008 \\
\hline 3 & 12 & 280 & 127 & 2250 & 57.8 & - & - & 30.1 & 0.1043 & 3.1394 \\
\hline 4 & 16 & 319 & 181 & 3850 & 102.5 & - & - & 70.6 & \begin{tabular}{|l|l|}
0.1492 \\
\end{tabular} & 10.534 \\
\hline 5 & 20 & 352 & 202 & 4239 & 106.7 & - & - & 77.3 & 0.1611 & 12.453 \\
\hline 6 & 24 & 380 & 220 & 4579 & 117.2 & - & - & 83.8 & 0.1932 & 16.19 \\
\hline
\end{tabular}
OF WATER PRESSURE

TABLE 8

MEASUREMENT OF WATER PRESSURE AND WATER DEBIT

\begin{tabular}{|c|c|c|c|c|c|}
\hline No & $\begin{array}{c}\text { Tekanan } \\
\text { Air (psi) }\end{array}$ & $\begin{array}{c}\text { Volume } \\
\text { Box (liter) }\end{array}$ & $\begin{array}{c}\text { Waktu } \\
(\mathrm{s})\end{array}$ & $\begin{array}{c}\text { Debit Air } \\
\text { (liter/s) }\end{array}$ & $\begin{array}{l}\text { Debit Air }( \\
\left.\mathrm{m}^{3} / \mathrm{s}\right)\end{array}$ \\
\hline 1 & 4 & 220 & 53 & 4 & 0.0040 \\
\hline 2 & 8 & 220 & 49 & 4.3 & 0.0043 \\
\hline 3 & 12 & 220 & 43 & 5 & 0.0050 \\
\hline 4 & 16 & 220 & 34 & 6 & 0.0060 \\
\hline 5 & 20 & 220 & 32 & 6.6 & 0.0066 \\
\hline 6 & 24 & 220 & 31 & 7 & 0.0070 \\
\hline
\end{tabular}

2. Calculation Of Hydrolic Power

Using equation 4 can be calculated Hydrolic Power

TABEL 9.

HYDRAULIC POWER CALCULATION

\begin{tabular}{|c|c|c|c|c|c|c|}
\hline No & $\begin{array}{c}\text { Water } \\
\text { Pressure } \\
\text { (psi) }\end{array}$ & $\begin{array}{c}\text { Density } \\
\text { of water }\end{array}$ & Gravity & $\begin{array}{c}\text { Water } \\
\text { discharge }\end{array}$ & $\begin{array}{c}\text { High } \\
\text { water } \\
\text { falls }(m)\end{array}$ & $\begin{array}{c}\text { Hydrolic } \\
\text { Power } \\
\text { (watt) }\end{array}$ \\
\hline 1 & 4 & 1000 & 9.81 & 0.0040 & 1.34 & 52.582 \\
\hline 2 & 8 & 1000 & 9.81 & 0.0043 & 1.34 & 56.525 \\
\hline 3 & 12 & 1000 & 9.81 & 0.0050 & 1.34 & 65.727 \\
\hline 4 & 16 & 1000 & 9.81 & 0.0060 & 1.34 & 78.872 \\
\hline 5 & 20 & 1000 & 9.81 & 0.0066 & 1.34 & 86.760 \\
\hline 6 & 24 & 1000 & 9.81 & 0.0070 & 1.34 & 92.018 \\
\hline
\end{tabular}

3. Calculation of efficiency and Torque

Using equation 5 and 6 can be calculated Eficiency and Torque. 
TABEL 10

CALCULATION OF EFFICIENCY AND TORQUE

\begin{tabular}{|c|c|c|c|c|c|c|}
\hline No & $\begin{array}{c}\text { Water } \\
\text { Pressure } \\
\text { (psi) }\end{array}$ & $\begin{array}{c}\text { Generator } \\
\text { Power } \\
\text { (Watt) }\end{array}$ & $\begin{array}{c}\text { Hydrolic } \\
\text { Power } \\
\text { (watt) }\end{array}$ & $\begin{array}{c}\text { Putaran } \\
\text { turbin } \\
\text { After } \\
\text { Coupled }\end{array}$ & $\begin{array}{c}\text { Efiiciency } \\
\text { PLTMH } \\
(\%)\end{array}$ & Torque \\
(Nm)
\end{tabular}

The results of measurements and calculations from each table that the effect of water pressure increases the torque, efficiency also increases. The maximum torque and efficiency at 24 psi is 0.703 nm and $17.594 \%$.

\section{CONCLUSION}

1. Test Results The microhydro prototype works well. In this study, the turbine angle at $40^{\circ}$ is very effective to produce the largest rotation (rpm) 301 before being combined, 173 after being combined, the largest generator rotation is $3765(\mathrm{rpm})$ and the highest power is the $40^{\circ}$ turbine angle with 10.91096 watts. If the turbine slope angle is lower than $40^{\circ}$, then some turbines will sink, so that the turbine rotation speed decreases, and vice versa, the turbine tilt angle higher than $40^{\circ}$ water becomes lower than the turbine end the volume of water flowing into the turbine decreases thereby reducing thrust to rotate the turbine. The greatest efficiency can be obtained at an angle of $40^{\circ}$ at the amount of $14.07 \%$ and the maximum torque is $0.60257 \mathrm{Nm}$.

2. Testing the change in water pressure on the Micro Hydro Power Plant model using Archimedes screw turbine, the result gets the best water pressure value of $24 \mathrm{psi}$, where the voltage, current, and power output generated from the generator are 83.88 Volt, 0.1932 Amperes and 16.19 Watts. For generator rotation speed generated $380 \mathrm{rpm}$ before being combined with generator (before coupled) and $220 \mathrm{rpm}$ after being combined (after coupled) with generator. The resulting torque is $0.73 \mathrm{Nm}$.
3. The biggest efficiency which got at this Micro Hydro Power Plants model is at pressure $24 \mathrm{Psi}$ as big as $17.594 \%$. The water pressure improvement will cause Micro Hydro Power Plants system efficiency increased, where this efficiency is influenced by hydraulic power and generator power. Bigger the pressure is given, thrust force from water flow will increase further and water speed which came out from fast pipe keep increasing that hydraulic power will get bigger power. Hydraulic power which had bigger power will cause generator power output increase even more then the efficiency at Micro Hydro Power Plants system become bigger than before.

\section{ACKNOWLEDGMENT}

On this occasion, the researcher are very greatful to research and community service of udayana university and ministry of research, technology and higher education with contribution conducting research compotitive grant scheme, so that the research could be conducted.

\section{REFERENCES}

[1] Subandono, A., 2012. Pembangkit Listrik Tenaga Mikro Hidro. Kediri : Universitas Pawyatan Daha Kediri.

[2] Herman Budi Harja, dkk, 2014, Penentuan Dimensi Sudu Turbin Dan Sudut Kemiringan Poros Turbin Pada Turbin Ulir Archimedes, Institut Teknologi Bandung.

[3] Adly Havendri, Irfan Arnif, 2010, Kaji Eksperimental Penentuan Sudut Ulir Optimum Pada Turbin Ulir Untuk Data Perancangan Turbin Ulir Pada Pusat Listrik Tenaga MikriHidro (PLTMH) dengan Head Rendah, Universitas Andalas, Padang.

[4] Rorres, C. 2000. The Turn of the Screw: Optimal Design of An Archimedes Screw. Journal of Hydraulic Engineering. Philadelphia.

[5] Tohari, M. 2015. Pengujian Unjuk Kerja Turbin Crossflow Skala Laboratorium dengan Jumlah Sudu 20. Sekolah Tinggi Teknik Harapan 
[6] Hanmandlu, M., Goyal, H., Kothari, D. P., 2006. "An Advanced Control Scheme for Micro Hydro Power Plants," in International Conference on Power Electronics, Drives and Energy Systems, 2006. PEDES '06, pp. $1-7$.

[7] Sakurai ,T ., Funato, H ., Ogasawara, S., 2009. "Fundamental characteristics of test facility for micro hydroelectric power generation system," presented at the International Conference on Electrical Machines and Systems. ICEMS .pp. 1-6

[8] Setiarso, M.A. Widiyanto, W. Purnomo, S.N. 2016. Potensi Tenaga Listrik dan Penggunaan Turbin Ulir
Untuk Pembangkit Skala Kecil di Saluran Irigasi Banjarcahyana. DINAMIKA REKAYASA Vol. 13 No. 1 (2016), Hal. 18-27

[9] Songin, K. 2017. "Experimental Analysis of Archimedes Screw Turbines". Canada : University of Guelph.

[10] Yul Hizhar,dkk, 2017, Rancang Bangun Dan Studi Eksperimental Pengaruh Perbedaan Jarak Pitch Dan Kemiringan Poros Terhadap Kinerja Mekanik Model Turbin Ulir 2 Blade Pada Aliran Head Rendah, Universitas Andalas, Padang. 